\title{
Properties of Cubic Cadmium Series Pigments ${ }_{\text {UDC }}^{667.622 .114 .851 .1}$ $: 548.021$
}

\author{
Makoto Tsunashima \\ Mitsubishi Metal Mining Co., Ltd.
}

\begin{abstract}
Cadmium pigments consist of solid solutions of $\mathrm{CdS}, \mathrm{ZnS}, \mathrm{CdSe}$ etc. at various ratios.

They have two crystal forms in normal conditions, i.e. zincblende ( $\beta$-type) and wurtzite ( $\alpha$-type) $\beta$-type is stable at temperatures lower than about $450^{\circ} \mathrm{C}$. But, the stable and brilliant $\beta$-type pigments have not been manufactured until now.

We have prepared the stable $\beta$-type CdS and the $5 \mathrm{CdS} \cdot \mathrm{ZnS}$ pigments in highly crystalline powder form and brilliant color. Some pigment characters of these new type were compared with those of conventional $\alpha$-type pigments.

The obtained results were as follows. The $\beta$-type was practically stable below $500^{\circ} \mathrm{C}$ heat treatment and weather resistant in color change and crystalform. Moreover its dispersiblity in plastics was better than that of $\alpha$-type.

The $\beta$-type pigments proposed here seem to be hopeful for the future pigment industry.
\end{abstract}

\footnotetext{
* Kitahukuro, 1-190, Omiya
} 
色材， $43(1970)$

\section{立方晶力ドミウム系顔料の物性}

綱
UDC

667.622 .114 .851$.

$: 548.021$

要 旨

カドミウム系顔料は硫化カドミウムを中心とした顔料で, 六方晶特よび立方晶の結晶のほか高压 飞执いて岩塩型の結晶が存在する。しかし現在市販されている顔料は六方晶の結晶粉体であり, 安 定した立方晶カドミウム系顔料の製造法はまだ開発されていない。本研究に和いては立方晶で結晶 性が高く，色調の鮮明な試料を作成した。これらのうち CdS 和よび $5 \mathrm{CdS} \cdot \mathrm{ZnS}$ の組成をもった 立方晶と六方晶の試料に対して各種顔料特性を比較した。

その結果，立方晶顔料の耐熱性，耐候性和よび色調は約 $500^{\circ} \mathrm{C}$ 以下の使用条件では従来の六方晶 と同等めるいはそれ以上の安定性をもち，特にカドミウム系顔料の主要用途であるプラステックス 中への分散性は六方晶よりもはるかにすぐれているという結果を得たのでここに報告する。

\section{1. 緒言}

硫化カドミウム系顔料とは, 硫化カドミウムを主体と 乙，それに硫化亜鉛，セレン化カドミウムめるいは硫化 水銀を適当量の割合に固溶体化させた結晶粉体顔料であ る。 $\mathrm{Zn}, \mathrm{Cd}, \mathrm{Hg}$ のカルコゲン $(\mathrm{O}, \mathrm{S}, \mathrm{Se})$ 化合物は全 域置換型の固溶体を形成するので色調も固溶体組成飞応 じて連続的汇変化する。中心となる硫化カドミウムは黄 色でめり，亜鉛量が増すと淡黄色側に移行し，セレン化 カドミウムあるいは硫化水銀が增加寸ると赤色を経て栗 色にいたる鮮明な色調をるっている。カドミウム系顔料 は同じ色調をもつ他の有機, 無機の黄色系扣よび赤色系 顔料に比較して耐熱性，耐候性を始めとする諸物性がす ぐれているためプラスチックス着色材を中心広く用い られている。

硫化カドミウム系結晶には高温安定形の $\alpha$ 型（六方晶 のWurtzite 型) 結晶执よび低温安定形の $\beta$ 型（立方晶 Zincblende 型) 結晶がある。また一部高圧安定型とし て最近，岩塩型構造が見いだされ報告されている1)。こ れら結晶形による色調の違いは $\alpha$ 型 $\mathrm{CdS}$ が黄色， $\beta$ 型 $\mathrm{CdS}$ が橙色であり，岩塩形は明らかではない。Edwards ら 2) によるエネルギーギャップ值からの概算によっても $\beta$ 型は $\alpha$ 型より赤色側に寄っていることがわかる。

現在市販されている硫化カドミウム系顔料は, 溶液反 応で沈殿させた立方晶もしくはとれに近い低結晶性の微

昭和 45.7.30 受理

* 三菱金属鉱業株式会社 大宮工場技術課 埼玉県大宮市北垡町 $1-190$
粉体を $500 \sim 800^{\circ} \mathrm{C}$ 飞熱処理したもので，すべて高温安 定形の六方晶形結晶粉体である。しかし本研究では従来 得られなかった高結晶性の立方晶形結晶粉体で, かつ鮮 明な色調をもち分散性のすぐれた顔料を作成し，この顔 料の諸物性を従来の六方晶形の顔料と比較実験を行なっ たので報告する。

\section{2. 実験}

試料は溶液反応拉よび加熱処理によって作成した CdS 扣よび $5 \mathrm{CdS} \cdot \mathrm{ZnS}$ の六方晶和よび立方晶の結晶形をも った粉体で，粉末X線回折図形は図-1 に示した通りで ある。これを解析した結果は格子ゆがみはほとんどな く, 単結晶子径は約 $800 \AA$ 程度であった。また顔料とし て重要な色調も鮮明であった。

これら試料は，それぞれ $100^{\circ} \mathrm{C}, 200^{\circ} \mathrm{C}, 400^{\circ} \mathrm{C}, 500$ ${ }^{\circ} \mathrm{C}, 600^{\circ} \mathrm{C}$ の温度で密封管状师内で 60 分間加熱処理さ れ, 水洗, 乾燥, 粉劯後測定に供した。

\section{1 耐 熱性}

耐熱性は各熱処理試料に対して粉末 X線回折法による 立方晶から六方晶への転移温度, 同じく単結晶子径の変 化抒よび色調の変化を測定してそれら物性の安定性と耐 熱性（耐熱温度）を求める手段とした。

$\mathrm{X}$ 線回折はカルサイト $\left(\mathrm{CaCO}_{3}\right)$ を内部標準として 10 重量\%混合し， $\mathrm{Cu} の \mathrm{~K}-\alpha$ 線（Niフィルター）を用い て測定した。

色調変化は東洋理化製の色差計を使用してハンターの $L, a, b$ の值を直読し, 次式によってハンターの色差を 算出した。 


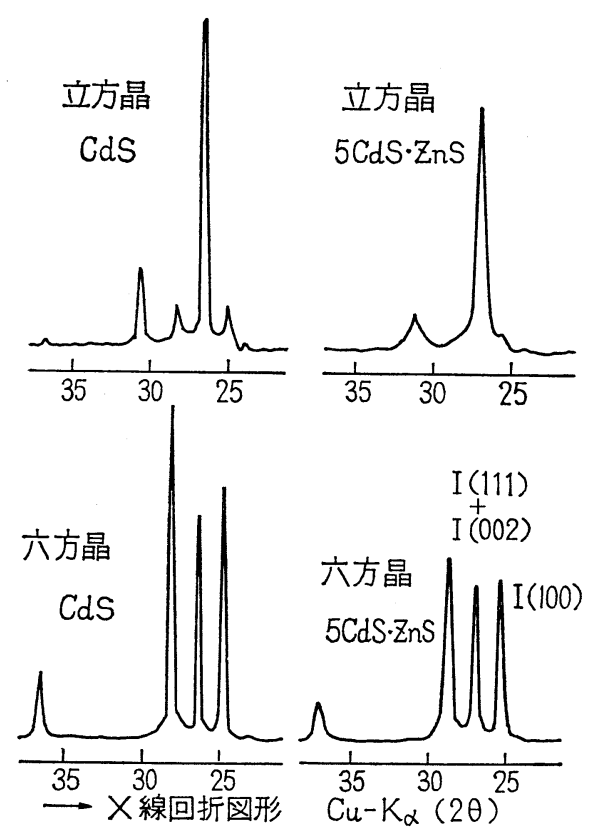

図-1 X 線回折図形 $\mathrm{Cu}-\mathrm{K}_{\alpha}(2 \theta)$

$$
\Delta E=\left(L^{2}+a^{2}+b^{2}\right)^{1 / 2}
$$

\section{2 耐候 性}

耐候性は顔料 1 重量\%を軟質塩化ビニル樹脂中に 150 ${ }^{\circ} \mathrm{C} ， 10$ 分間熱ロール上で練和し，それを $150 \mathrm{~kg} / \mathrm{cm}^{2}$ で プレスした試料片を屋上に 1 カ月（1968 年 7 月）間暴露 した。試料の未暴露および 15 日，30 日間暴露を行なっ たものに対して前記と同様の方法で色差を測定した。

\section{3 分 散 性}

試料の樹脂中への実際の分散性は, 試料 1 重量\%をポ リエチレン中に熱ロールで $140^{\circ} \mathrm{C} ， 10$ 分間練和を行ない それをプレスした薄片を光学顕微鏡写真で撮影した。同 じ写真を数視野撮影して平均的な分散性のものを示し た。

\section{3. 結果および考察}

\section{1 結晶転移の安定性}

試料 4 種類の $X$ 線回折図形を図-1 に示す。六方晶, 立方晶部分の定量は Short $ら^{3)}$ の提出した実験式を一部 修正した式を適用した。どららの式についても絶対值で はないが，相対值として使用するので大差はない。これ は次式で表わされ式中の $R$ は図-1 に示される六方晶の 及の (100) 面による回折強度に対する六方晶の (002) 面 特よび立方晶の (111) 面による回折ピークの重なったピ ークの回折強度の比を表わす。また $\mathrm{H} は$ 試料中に含まれ る六方晶結晶部分の割合を表わす。

$$
R=I(100) /\{I(002)+I(111)\}
$$

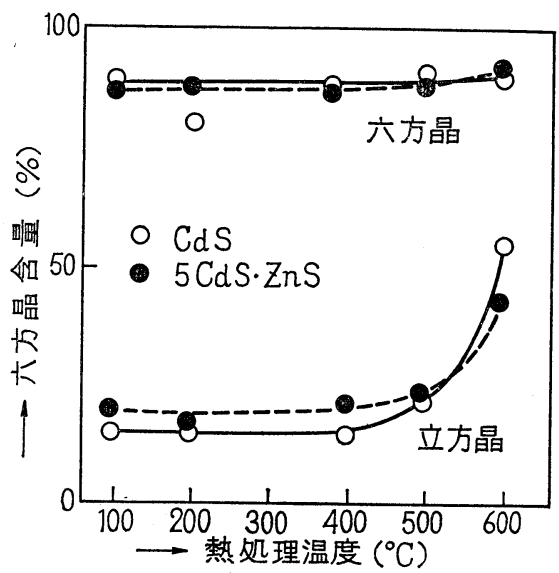

図-2 熱処 理 温度

$$
=1.70 H /(4-3 H)
$$

立方晶結晶は本来低温安定形であり, 結晶形は加熱処 理によって高温安定型の六方晶に転移する。したがって 立方晶結晶の耐熱温度は, この転移が急激に起こる温度 といえる。しかし CdS 結晶は常温でも六方晶, 立方晶 とも実際上安定に存在し, 転移点もはっきりしない。図 -2 より六方晶の試料は高温安定型であるから $600^{\circ} \mathrm{C}$ ま で汪とんど変動しないのは当然であるが，立方晶の試料 は $500^{\circ} \mathrm{C}$ 以上の温度では急激な六方晶への転移が起こ る。したがって立方晶結晶の実際上の転移安定性は 500 ${ }^{\circ} \mathrm{C}$ であるといえる。

\section{2 単結晶子径の安定性}

図-3にはX線回折図形から算出した単結晶子径の熱 処理温度による変化を示した。六方晶の結晶は約 $500^{\circ} \mathrm{C}$ 以上で単結晶子径の急激な成長が起こる。一方立方晶試 料では前述のように結晶転移も同時に起こる温度なので $500^{\circ} \mathrm{C}$ 以上の熱処理によって結晶転移が起こり結晶成長 が遅れるものと考兄られ, 結果的に単結晶子径は小さく

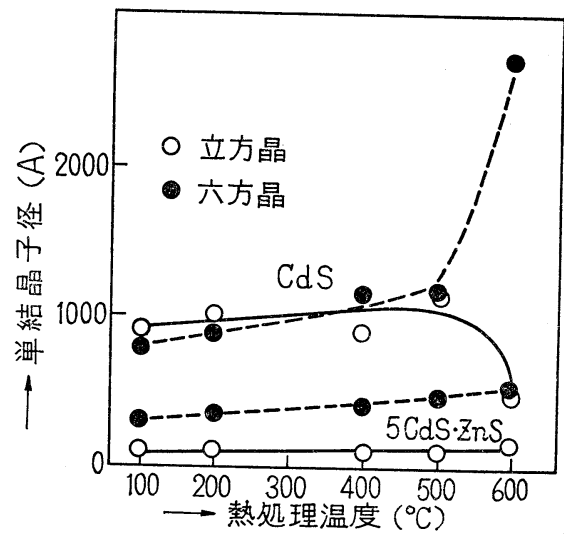

図-3 熱処 理温度 
なった。

固溶体 $(5 \mathrm{CdS} \cdot \mathrm{ZnS})$ に関しては六方晶, 立方晶とも 飞 $600^{\circ} \mathrm{C}$ 付近までは単結晶子径の变化が少なく安定であ った。これは試料が固溶体組成のため, CdS のみの場合 より結晶成長が遅くなるためと考えられる。

以上のように結晶形执よび単結晶子径の変化からは, 立方晶顔料の結晶安定性は $500^{\circ} \mathrm{C}$ までであることがわか る。本害験で使用した立方晶試料は図-1 に示されるよ らに結晶性が良いため熱に対して安定性が高いものと考 えられる。

\section{3 色調の安定性}

熱に対する色調変化の実験結果を図-4 および図-5に 示す。図-4 は $\mathrm{CdS}$ の色調変化を, 図-5には $5 \mathrm{CdS} \cdot \mathrm{ZnS}$ の色調変化を測定し，図示したものである。たて軸は前 述したハンターの色差であり, 絶対值ではなく, 実験条 件によって子変化するので，相対値を比較して解折す る。

図-4 执よび図 -5 から，立方晶顔料の色調変化は従来 の六方晶顔料と比較して同等あるいはそれ以上の安定性

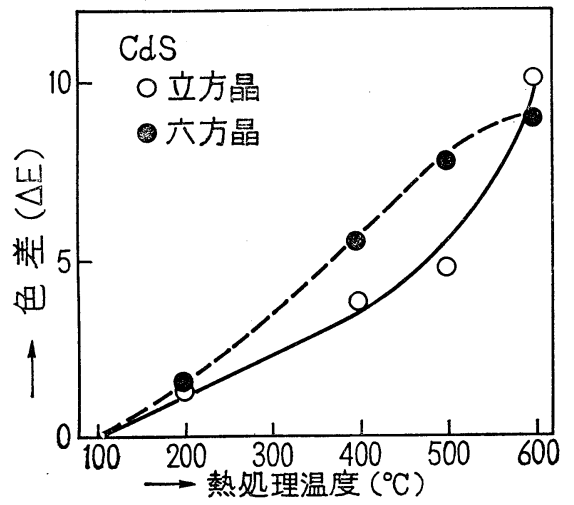

図-4 熱処 理温度

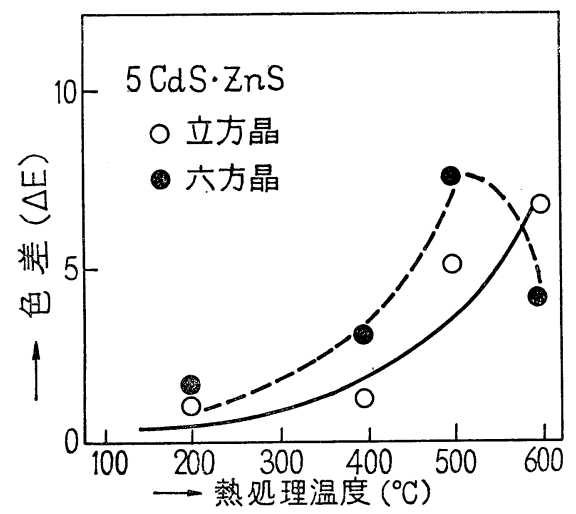

図-5 熱処 理 温度
をもっている。しかし $500^{\circ} \mathrm{C}$ 以上になると六方晶，立方 晶ともに色調変化は著しくなる。したがって立方晶顔料 の色調の耐熱性は $500^{\circ} \mathrm{C}$ であるとい方る。六方晶顔料も $500^{\circ} \mathrm{C}$ 以上で色調変化を起こすのは 3.2 で述べたように 結晶粒子の大幅な成長のためであろう。

\section{4 耐 候 性}

カドミウム系顔料は一般に耐候性が良いといわれてい るが，六方晶と立方晶の試料の夏季（7月）に拈ける屋 外暴露による色調変化を測定した。未暴露試料との色差 を測定した結果を図-6 に示す。四から明らかなように, 立方晶顔料の耐候性は六方晶と同等あるいはそれ以上の 結果となった。また $\mathrm{ZnS}$ が固溶体化してくると CdS の みの場合よりかなり耐候性は悪くなる傾向があるのは両

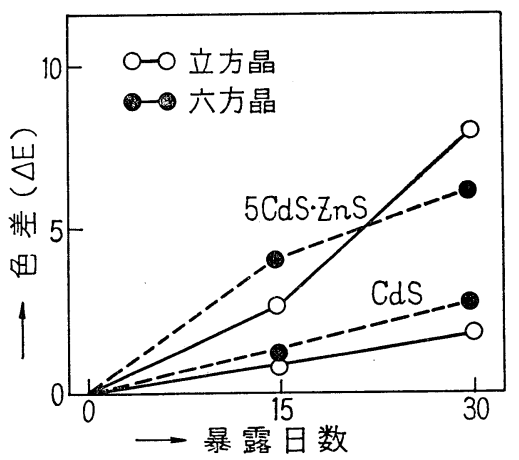

図-6 暴 露 日 数

$\mathrm{CdS}$

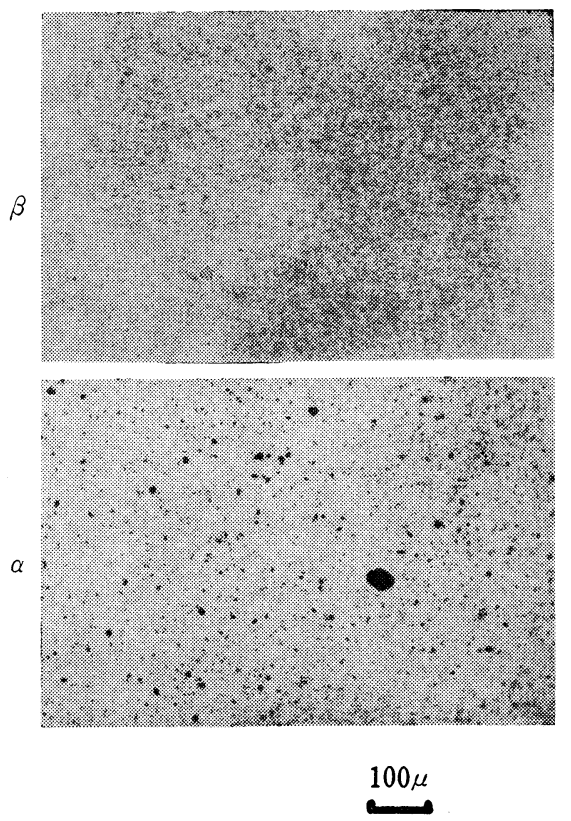

写真-1 立方晶カドミウム系顔料の物性 


\section{$5 \mathrm{CdS} \cdot \mathrm{ZnS}$}

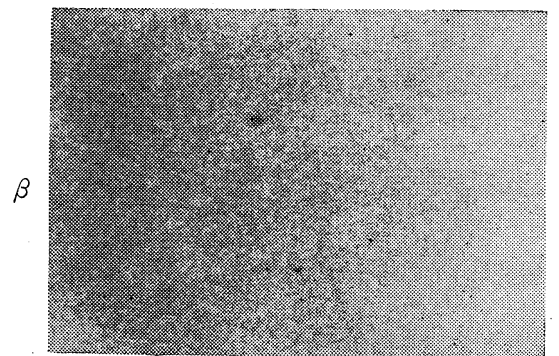

$\alpha$

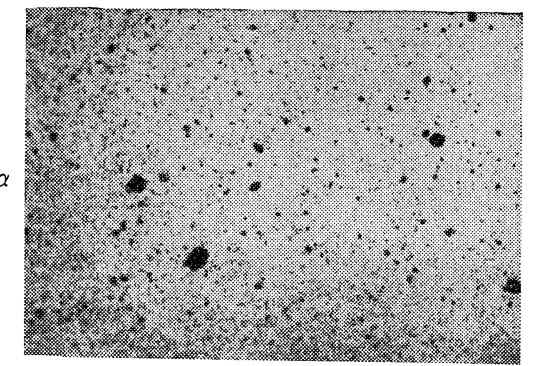

$100 \mu$

写真-2 立方晶カドミウム系顔料の物性 結晶型に共通であった。

\section{5 分散性}

写真-1 飞 CdS 組成の試料の分散写真を, また写真-2 に $5 \mathrm{CdS}-\mathrm{ZnS}$ 固溶体組成の試料の分散写真を示した。 図から明らかなよ5に，立方晶顔料は六方晶顔料に比較 して粗大粒子を含まないすぐれた分散性を持つことが認 められる。通常カドミウム系顔料の主要用途であるプラ ステックスに扎いては, 練和時の粘性が低く, 顔料粒子 に働くセン断力は弱い。そのため凝集の弱い立方晶顔料 の粒子は容易に分離されて単一粒子になりやすいが，比
較的凝集の強い六方晶顔料の粒子は, より長時間の練和 を要することになる。この結果, 立方晶顔料は, 六方晶 顔料に比較して分散しやすいと考兄られる。

\section{6 その他}

以上のように立方晶カドミウム系顔料の結晶（粒子） や色調の耐熱性, 耐候性に限界があるにしても, 高温安 定型結晶の六方晶に匹敵する特性をもった立方晶顔料が 得られた。特に主要用途であるプラスチックス系へは耐 熱性，耐候性も充分であり，さらに分散性がすぐれてい る。従来は立方晶といっても無定形あるいはそれに近い ものを含んだ低結晶性の粉体が得られるのみで, それら は微粒子の上，色調も暗赤色で鮮明でない。一方図-1 に示される結晶で粒子径も現在の六方晶程度であれば充 分に顔料として使用できる特性を備えていることが確か められた。

\section{4. 結 論}

立方晶カドミウム系顔料は, 結晶性さえ良ければ色調, 耐熱性，耐候性は六方晶に匹敵する。

さらにプラスチックス着色材としては従来の六方晶の ものより分散性は良いことが見いだされた。

本報告をなとめるに当たり，三菱金属中央研究所長 佐藤享一郎氏括よび東大生産技術研究所第 4 部高橋浩 助教授に御助言いただいたことに謝意を表する。

\section{文献}

1) J.A.Corll, J. Appl. Phys., 35, 3032 (1964)

2) A.L.Edwards, T.E.Slykhouse, H. G. Drickamer, J.Phys. Chem. Solids, 11, 140 (1959)

3) M. A.Short, E. G. Steward, Am.Min., 44, 189 (1959) 